\title{
16. Conclusion: The European Convention on Human Rights as a common European endeavour
}

\section{Julie Fraser*}

The European Court of Human Rights ('ECtHR' or 'the Court') is a unique body that has played a pivotal role in strengthening the protection of human rights across Europe for over half a century. ${ }^{1}$ Its impact and inspiration extends globally, as it has been emulated and its jurisprudence argued in courts far beyond the bounds of Europe. Both the critics and proponents of the Court in this volume agree that it has long been part of the most advanced and successful human rights regime in the world. There is also consensus that, notwithstanding the Court's achievements in human rights, the Convention system is far from perfect. It is clear from the chapters in this volume that it is not only the critics who seek reform of the Court.

As Sajó wrote, the Convention for the Protection of Human Rights and Fundamental Freedoms ('ECHR' or 'the Convention') 2 is about a Europe based on a shared value of human rights and the 'willingness to accept Europe as unified by a common understanding' of such rights. ${ }^{3}$ Given the (increasing) size and scope of both the Council of Europe and the Convention, it is not surprising that determining and maintaining such a 'common understanding' is proving difficult. The Court, tasked with interpreting and applying the Convention, has faced growing criticism regarding both its practice and procedure. While there may or may not be

\footnotetext{
* All opinions expressed are personal.

1 European Court of Human Rights, High Level Conference on the Future of the European Court of Human Rights, Brighton Declaration (20 April 2012) para 2 .

2 Convention for the Protection of Human Rights and Fundamental Freedoms (4 November 1950, Europ.T.S. No. 5; 213 UNTS 221).

3 András Sajó, 'An all-European conversation: Promoting a common understanding of European human rights', chapter 15, p. 186.
} 
danger in overestimating the problems facing the Court, there is certainly danger in underestimating them. Whether one agrees with the criticism of the Court expressed in this volume or not, the Strasbourg system will be jeopardised if such criticism is left unanswered.

This concluding chapter considers the issues and criticism raised in the preceding chapters regarding the 'backlog' and the 'backlash' that the Court faces, with a focus on the implications for the Court's legitimacy. The second part of the chapter addresses the proposed solutions to some of the criticism, including an enhanced role for the Committee of Ministers and greater dialogue and interaction between the Court and national courts and legal systems. In the final part this chapter looks ahead to the future of the Court and the need to ensure its vitality, effectiveness and authority for the benefit of Europe and everyone within its jurisdiction.

\section{CRISIS, WHAT CRISIS? THE BACKLOG AND BACKLASH}

It is apparent from the preceding chapters that the current 'backlog and backlash' are the biggest problems facing the Court and that they are interrelated. Among the criticism discussed in this volume are the allegations that the Court's legitimacy is slipping, that its legal reasoning is poor and its jurisprudence inconsistent, that the Court neglects the Convention system's subsidiarity principle and embraces expansive interpretations of rights beyond the text of the ECHR. It is necessary to consider the current context, or zeitgeist, in Europe as the background to this criticism.

Previously, we may have interpreted a discussion about 'criticism and the ECtHR', as criticism by the Court of recalcitrant member States for their poor human rights practices. It is telling that the tables have turned and that we are now concerned with criticism from certain member States - and some within their jurisdiction - of the Court itself. The reasons for the growing criticism, it has been suggested, include a retreat to sovereignty arising from terrorism and security concerns, the economic crisis, Euroscepticism and the growing influence of popularist movements. ${ }^{4}$ The

4 Luzius Wildhaber, 'Criticism and case-overload: Comments on the future of the European Court of Human Rights', chapter 2, p. 9. 
zeitgeist concerning EU integration is rather negative, with resurgent calls for greater emphasis on national decision-making as opposed to European coordination and supervision. Whatever the reasons for the growing criticism, it is apparent that the criticism is not going away by itself and that it must be addressed.

\section{The Court's Substantial and Growing Backlog}

After 50 years, the Court risks being a casualty of its own success. The pool of potential applicants to petition the Court is vast, encompassing some 800 million inhabitants of greater Europe. The number of applications made to the Court each year has doubled since 2004 and a significant backlog of applications exists. ${ }^{5}$ At the end of 2011 the waiting time for communication - not determination - of a case was 37 months. The ever-growing caseload not only threatens the long-term viability of the Court, it also visits an injustice on those who are genuinely in need and who look to the Court for protection of their rights. ${ }^{6}$ As discussed by Wildhaber, Myjer and Mahoney, this backlog represents a structural and systemic problem for the Court.

Member States have held High Level Conferences to address the issue of the backlog and to find solutions. States have reacted by introducing remedial measures such as Protocol No. 14 ECHR, pilot judgments, reducing the deadline for applications from six months to four, applying a prioritisation policy to applications, ${ }^{7}$ and appointing additional judges to process applications. ${ }^{8}$ Overall, the number of striking-out and inadmissibility decisions increased by 31 per cent in 2011 compared to 2010. As a result the Court estimates that it will have dealt with the backlog of

5 Brighton Declaration (20 April 2012) supra n 1, para 16. At the end of 2011, more than 151,600 allocated applications were pending before the Court. European Court of Human Rights, Annual Report 2011 of the European Court of Human Rights, Council of Europe (Strasbourg March 2012) para 9, page 13.

6 Lord Woolf, Michael McKenzie CB QC, Peter MacMahon, Dr. Colm O'Cinneide and Laura Clarke, Review of the Working Methods of the European Court of Human Rights (December 2005) page $8<\mathrm{http}: / /$ www.echr.coe.int/ ECHR/EN/Header/The+Court/Reform+of+the+Court/Reports/> accessed on 13 October 2012; and Paul Mahoney, 'The European Court of Human Rights and its ever-growing caseload: Preserving the mission of the Court while ensuring the viability of the individual petition system', chapter 3, p. 25.

7 This policy was commended in the Brighton Declaration for helping the Court to focus on the most serious cases. Brighton Declaration (20 April 2012) supra n 1, para 20(a)(i).

8 Ibid, see generally. 
applications by $2015 .{ }^{9}$ However, despite these positive developments and predictions the backlog continues to mount, increasing by some 12,300 applications in 2011. ${ }^{10}$ At the 2012 High Level Conference in Brighton, it was noted that the measures implemented to date will not provide a lasting solution to the problems facing the Court. ${ }^{11}$ The member States agreed that the future of the Court and longer-term measures also need to be carefully considered. ${ }^{12}$

Cutting corners to improve speed and productivity is not the solution, for, as noted by Zwart and Mahoney, the number of judgments cannot be increased without reducing the consistency and quality of judgments. ${ }^{13}$ Simply boosting staff and resources might not be viable either. The number of staff in the Court's Registry in 2005 was 521, a number that had doubled in the preceding six years. At that time, internal and external audits estimated that the Court needed 1280 additional staff: 660 for coping with incoming applications and 620 for tackling the backlog of applications. ${ }^{14}$ However, at the end of 2011 the Registry had only grown modestly to 658 staff members. ${ }^{15}$ As Opstelten noted in his Foreword to this volume, although some States have seconded lawyers to the Registry, which is helping the Court to process applications, significant increases in the Court's resources are unlikely in the current financial climate. ${ }^{16}$ Mahoney goes further, stating that it is inconceivable that the Court should have the material capacity to consider the merits of all human rights complaints within a Convention community of 800 million people. ${ }^{17}$

9 Ibid, para 20(b).

10 European Court of Human Rights, Annual Report 2011 (Strasbourg March 2012) supra n 5, Foreword.

11 Brighton Declaration (20 April 2012) supra n 1, para 6.

12 Ibid, paras 20, 30 and 35.

13 Tom Zwart, 'More human rights than Court: why the legitimacy of the European Court of Human Rights is in need of repair and how it can be done', chapter 8, pp. 86; and Paul Mahoney, supra n 6, p. 20.

14 Lord Woolf et al, supra n 6, page 11.

15 European Court of Human Rights, Annual Report 2011 (Strasbourg March 2012) supra n 5, para 28, page 19.

16 Ivo Opstelten, 'Foreword', p. xii.

17 Paul Mahoney, supra n 6, p. 22. See also Janneke Gerards and Ashley Terlouw, 'Solutions for the European Court of Human Rights: The Amicus Curiae Project', chapter 14, p. 162. 


\section{The right of individual petition: saving vs reforming}

The mechanism of individual petitions to the ECtHR is a means by which failings in the national protection of human rights are detected and remedied at the international level. ${ }^{18}$ In the Brighton Declaration member States reaffirmed their attachment to the right of individual application as a cornerstone of the ECHR system. ${ }^{19}$ However, as Wildhaber proposed, the bottleneck is not necessarily in the Court's Registry where the applications are processed - but rather in the head. A clearer sense of proportion and a realistic understanding of the ECtHR and its capacity are required. There is a danger that this persistence will not 'save' the right but instead undermine the credibility of the individual application system and the Court. ${ }^{20}$ It should be recalled that over 90 per cent of applications to the ECtHR are deemed inadmissible. ${ }^{21}$ This high percentage suggests an incongruence between the expectations of those who apply and what the Court was intended to, and can in fact, deliver. ${ }^{22}$ It reveals a lack of awareness and understanding as to the Court's real purpose and jurisdiction. ${ }^{23}$

Wildhaber argues that as not everything is possible, it may be that the individual application system needs to be reformed rather than retained as is. ${ }^{24}$ Mahoney commented that in the circumstances of the backlog and delay, it may be preferable for the Court to inform an applicant that it is unable to deal with the applicant's case rather than having the applicant wait years (potentially in vain) for a determination. Wildhaber proposed not to wait for the time-consuming formal determination process, but to invite the Court to continue 'its creative search for innovative and realistic means for effectively managing its caseload within the existing framework, but extending it as far as possible'. ${ }^{25}$ As it stands, the Committee of Ministers will carry out a comprehensive analysis of

18 See generally Lucian Bojin, 'Challenges facing the European Court of Human Rights: fragmentation of the international order, division in Europe and the right to individual petition', chapter 6, pp. 60-64.

19 Brighton Declaration (20 April 2012) supra n 1, paras 2 and 13.

20 Luzius Wildhaber, supra $\mathrm{n}$ 4, see p. 16.

21 European Court of Human Rights, Annual Report 2011 (Strasbourg March 2012) supra n 5, para 17, page 16 .

22 Lord Woolf et al, supra n 6, page 10.

23 Ibid.

24 Luzius Wildhaber, supra n 4, p. 16.

25 Ibid. 
options for the future role and function of the Court, including consideration of more significant changes to how applications are determined, with the aim of reducing the number of cases before the Court. ${ }^{26}$

\section{Backlash: Criticism of the Court's Judgments and Procedures}

As introduced by Opstelten in the foreword, while the backlash against the Court is less tangible than the issue of the backlog, it is more pervasive. ${ }^{27}$ Much of the criticism relates to the Court's authority and legitimacy, which has wider implications for democratic accountability and the acceptance and enforcement of the Court's decisions. There is a view that ECtHR judges too easily depart from their own case law and too easily overturn decisions taken by democratically elected governments. The backlash is somewhat perplexing as, based on the sheer number of applications submitted annually, it would seem self-evident that the people of Europe value the Court and seek to rely on it to protect their rights.

The Court has been accused of expanding the notion of human rights as contained in the ECHR beyond the scope originally contemplated. Some critics have noted that this expansive interpretation is a cause of the Court's increased workload and the unmanageable backlog of applications. Zwart and Bossuyt both rely on the example of the Court's interpretation of the binding nature of interim measures to make this point. Bossuyt further extrapolates that in asylum cases the Court has continuously lowered the threshold for applications while widening the ambit of 'vulnerable' groups. ${ }^{28}$ He laments the extension of the ECHR's scope to economic and social rights and the identification of minimum standards for such rights - the achievement of which is untenable for many member States. ${ }^{29}$ The latest development often cited for criticism is the extraterritorial effect given to the ECHR by the Court in Al-Skeini, Al-Jedda and Abu Qatada. ${ }^{30}$

\footnotetext{
26 Brighton Declaration (20 April 2012) supra n 1, para 35(e).

27 Ivo Opstelten, supra n 16, p. xii.

28 Marc Bossuyt, 'Is the European Court of Human Rights on a slippery slope?', chapter 4, pp. 29-31.

29 Ibid, pp. 35; and Lucian Bojin, supra n 18, p. 59.

30 Al-Skeini v. The United Kingdom App no 55721/07 (ECHR 7 July 2011); Al-Jedda v. The United Kingdom App no 27021/08 (ECHR 7 July 2011); and Othman (Abu Qatada) v. The United Kingdom App no 8139/09 (ECHR 17 January 2012). For a greater discussion on the extraterritoriality of the Convention see Lucian Bojin, ibid, pp. 54-58.
} 


\section{Precedent and the 'living instrument'}

Authors in this volume agree that the Court is not bound by its previous decisions. It can equally be agreed that while such decisions are not binding, precedent should not be departed from without good reason. The legitimacy of judicial rulings is guarded by the principles of consistency, legal certainty and predictability. ${ }^{31}$ Legal certainty is vital if national courts are expected to follow and apply Strasbourg case law and to do so without the fear that it will be easily overturned. ${ }^{32}$ However, precedents can and sometimes should be distinguished when societal change and present day conditions require an alteration to the established case law. ${ }^{33}$ The Court has long stressed that the Convention is a 'living instrument' to be interpreted in light of evolving circumstances. ${ }^{34}$ In such situations, the Court should not surprise parties with arbitrary results, but should plainly articulate the logic behind its decisions. ${ }^{35}$ Zwart contends that this is not the case in practice. He cites an example regarding the Dublin Regulation, ${ }^{36}$ where in MSS v. Belgium and Greece the Court chastised Belgium for sending an asylum seeker back to Greece as the first country

31 Kanstantsin Dzehtsiarou, 'European Consensus and the Evolutive Interpretation of the European Convention on Human Rights' (2011) 12 German L.J. 1730, 1741.

32 Brighton Declaration (20 April 2012) supra n 1, paras 23 and 25(c). Wilhelmina Thomassen, 'The vital relationship between the European Court of Human Rights and national courts', chapter 9, p. 101.

33 Bayatyan v. Armenia App no 23459/03 (ECHR Grand Chamber 7 July 2011) paras 98 and 102; and Cossey v. The United Kingdom (1990) Series A no 184, para 35. See also Nicole Bürli, 'Amicus curiae as a means to reinforce the legitimacy of the European Court of Human Rights', chapter 12, p. 138; and Egbert Myjer, 'Why much of the criticism of the European Court of Human Rights is unfounded', chapter 5, p. 49.

34 See e.g. Tyrer v. The United Kingdom (25 April 1987) 2 EHRR1, para 31; Kress v. France App no 39594/98 (ECHR Grand Chamber 2001-VI) para 70; and Christine Goodwin v. The United Kingdom App no 28957/95 (ECHR Grand Chamber 11 July 2002) para 75.

35 Kanstantsin Dzehtsiarou and Alan Greene, 'Legitimacy and the Future of the European Court of Human Rights: Critical Perspectives from Academia and Practitioners', 12 German L.J. 1707 (2011) 1708.

36 Council Regulation (EC) No 343/2003 of 18 February 2003 establishing the criteria and mechanisms for determining the member State responsible for examining an asylum application lodged in one of the member States by a third-country national. 
of arrival, despite its ruling only six months earlier in $K R S v$. The $U K$ that it was acceptable to do so. ${ }^{37}$

Criticisms regarding the Court's consistency and clarity of reasoning are critical and must be met by the Court. As Bürli noted, the Court derives its legitimacy in part from well-reasoned and consistent judgments. She highlighted the role that amicus curiae briefs can play in assisting the Court with information to aid continuity and sound deliberation. ${ }^{38}$ Acknowledging the importance of consistency, the Court created the position of Jurisconsult, who is responsible for monitoring case law and plays a key role in preventing conflicts in jurisprudence. ${ }^{39}$ The Court has also indicated that it is considering making it obligatory for a Chamber to relinquish jurisdiction to the Grand Chamber where it envisages departing from settled case law. ${ }^{40}$ Zwart welcomed such a proposal, but queried whether it will assist in cases where the Court appears to overturn its previous case law unintentionally. ${ }^{41}$

As noted above, some critics have blamed the 'living instrument' approach to interpretation and tendency towards judicial activism as a cause of the Court's increased workload. However, others contend that the overwhelming number of applications from certain member States is the primary contributing factor to the Court's backlog. Over 60 per cent of applications pending in 2012 come from just five out of 47 member States. ${ }^{42}$ This points to the systemic human rights issues in those States as the cause of the increased workload, rather than rampant judicial activism on the Court's behalf.

\section{Legitimacy or democratic deficiency?}

Critics have argued that the living instrument doctrine amounts to the creation of new rights that interfere with parliamentary sovereignty and democratic accountability. An oft referred to example in this volume

37 Tom Zwart, supra n 13, p. 86. MSS v. Belgium and Greece App no 30696/09 (ECHR 21 January 2011); and KRS v. The United Kingdom App no 32733/08 (ECHR 2 December 2008).

38 Nicole Bürli, supra n 33, p. 137.

39 See Egbert Myjer, supra n 33, p. 48.

40 Brighton Declaration (20 April 2012) supra n 1, para 23.

41 Tom Zwart, supra n 13, p. 86.

42 Russia, Turkey, Italy, Romania and Ukraine. European Court of Human Rights, Pending Applications Allocated to a Judicial Formation (30 September 2012) <http://www.echr.coe.int/ECHR/EN/Header/Reports+and+Statistics/

Statistics/Statistical+data/> accessed on 13 October 2012. 
is the case of prisoner franchise in the UK in Hirst. ${ }^{43}$ Davis and Dzehtsiarou enumerated the occasions upon which the British people and Parliament reiterated their intention to restrict the franchise of prisoners. ${ }^{44}$ Relying on the sovereignty of the UK Parliament and the expressed will of the people, the UK Prime Minister refused to comply with the ECtHR's judgment in Hirst, which held the UK in violation of Article 3 Protocol No. 1 ECHR for restricting voting rights of prisoners. Undoubtedly, non-compliance with its judgments is a blow to the Court's legitimacy. In order to regain flagging legitimacy Zwart proposes that the Court refrain from such judicial activism as evinced in the Court's interpretation of Article 3 of Protocol No. 1 ECHR in Hirst to include a right to vote. ${ }^{45}$ In the circumstances, it is unsurprising that the Brighton Declaration, drafted under UK Chairmanship of the Committee of Ministers, urges the Court to utilise the margin of appreciation, which gives greater leeway to States in applying the ECHR, and embed the doctrine into the Convention's Preamble. ${ }^{46}$

Such 'democratic deficit' criticism of international human rights law is not new. ${ }^{47}$ While not a court of fourth instance, the ECtHR has supervisory jurisdiction over the member States' human rights practices. Dzehtsiarou argued that while the Court must consider the decisions of the democratically elected governments of member States, the Court should not abandon its harmonising role and allow national consensus to trump European consensus on human rights issues. ${ }^{48}$ The Court could be politically sensitive about the impact or timing of its decisions, but should not shy away from a ruling believed to be legally sound on the basis of it being politically unsavoury in a particular jurisdiction. As Sajó

43 Hirst v. The United Kingdom (No.2) App no 74025/01 (ECHR Grand Chamber 6 October 2005).

44 David Davis, 'Britain must defy the European Court of Human Rights on prisoner voting as Strasbourg is exceeding its authority', chapter 7, p. 65; and Kanstantsin Dzehtsiarou, 'Interaction between the European Court of Human Rights and member States: European consensus, advisory opinions and the question of legitimacy', Chapter 11, p. 123.

45 Tom Zwart, supra n 13, pp. 88-89. The text of Article 3 of Protocol No. 1 ECHR reads: 'The High Contracting Parties undertake to hold free elections at reasonable intervals by secret ballot, under conditions which will ensure the free expression of the opinion of the people in the choice of the legislature.'

46 Brighton Declaration (20 April 2012) supra n 1, paras 11 and 12(a) and (b).

47 Jamie Mayerfeld, 'The Democratic Legitimacy of International Human Rights Law' (2009) 19 Ind. Int'l and Comp. L. Rev. 49, 49-52.

48 Dzehtsiarou notes that European consensus not only facilitates interaction between member States and the Court but also enhances the legitimacy of the judgments. Kanstantsin Dzehtsiarou, supra n 44, p. 133. 
reminded us, modern constitutional theory stands for the separation of powers and accepts that courts have a proper role in countering national parliaments. ${ }^{49}$ The ECtHR, like all constitutional courts, must represent democracy under the rule of law, which is distinct from purely democratic decision-making. ${ }^{50}$ Thus, the Court does not need to always enjoy popularity with the majority, as the Court's role is also to protect the rights of minorities. Equally, as a supranational court adjudicating the practice of member States, popularity among such States may be unrealistic. 51

Judicial interpretation is required as the ECHR is broadly framed. By interpreting the Convention in present day conditions, courts are merely fulfilling their mandate. The ECtHR has oft reiterated that the Convention 'is intended to guarantee not rights that are theoretical or illusory, but rights that are practical and effective'. ${ }^{52}$ Cases are brought before the judges, raising new questions of law for them to answer; their decisions will often make law, regardless of the answer they give. ${ }^{53}$ This applies equally to national courts as well as to Strasbourg. Gerards and Terlouw found little support in their study for the argument that the Court is interfering too much with national sovereignty and democratic processes, noting that functioning in a political context does not mean that the Court itself is acting as a political body. ${ }^{54}$

And just as there are those like Davis, Bossuyt and Zwart who claim the Court is going too far, others contend that it is not going far enough. For example much criticism was raised in the case of $A, B$, and $C v$.

49 András Sajó, supra n 3, p. 187. See also Luzius Wildhaber, supra n 4, pp. 10-11.

50 Mayerfeld argues that in this way international human rights law strengthens rather than undermines democracy. Jamie Mayerfeld, supra n 47, 63.

51 Judge Stephen Breyer notes that when one considers how long it has taken the USA to accept the validity of Supreme Court decisions, it provides a sense of the daunting task that the European Court of Human Rights - 'a relatively new judicial institution' - is currently tackling. Stephen G. Breyer, 'The Present and the Future of the European Court of Human Rights: Introduction of President Luzius Wildhaber' (2006-2007) 22 Am. U. Int'l L. Rev. 517, 518 and 520.

52 See e.g. Airey v. Ireland App no 6289/73 (ECHR 9 October 1979) para 24.

53 Wilhelmina Thomassen, supra n 32, pp. 98-99.

54 Janneke Gerards and Ashley Terlouw, supra n 17, p. 169; and Ivo Opstelten, supra n 16, p. xii. 
Ireland ${ }^{55}$ where, despite a majority of European countries permitting abortion, the Court ruled against women's choice in Ireland. ${ }^{56}$ As this illustrates, the Court must walk a fine line and will receive criticism from both ends of the political spectrum.

Bossuyt expressed his concern noting that history has shown that what is exceptional in the first case, becomes mainstream in subsequent cases. ${ }^{57}$ This is what he calls the 'slippery slope'. It is, however, important to retain perspective on these issues as Myjer urges. Current leading cases were also once criticised at the national level, such as the Handyside case, ${ }^{58}$ but are now firmly part of the Court's acquis - or the accumulated acts and decisions that constitute the law of the Convention system. ${ }^{59}$ This acquis is the basis for human rights protection in Europe. It is arguable that these cases criticised today, including Hirst, Al-Skeini and MSS v. Belgium and Greece, will in the future also form part of this important acquis of leading decisions.

\section{PROPOSED SOLUTIONS TO THE BACKLOG AND THE BACKLASH}

As noted above, over 60 per cent of applications pending before the Court in 2012 derive from just five out of 47 member States, which reveals systemic human rights issues in those countries. The workload situation should, therefore, not be blamed on the Court, but rather on the structural legal problems in member States and on the refusal of some

$55 A, B$, and $C$ v. Ireland App no 25579/05 (ECHR Grand Chamber 16 December 2010).

56 See e.g. Center for Reproductive Rights, Press release European Court of Human Rights Rules that Ireland Abortion Ban Violates Human Rights, But Doesn't Go Far Enough (16 December 2010) <reproductiverights.org/en/pressroom/european-court-of-human-rights-rules-that-ireland-abortion-ban-violateshuman-rights-but-> accessed on 13 October 2012. Criticism of Ireland's abortion law was voiced by several states (Slovenia, Spain, Denmark, the Netherlands, Norway and the UK) at Ireland's Universal Periodic Review hearing before the UN Human Rights Council 2011. See UN Human Rights Council $19^{\text {th }}$ Session, Universal Periodic Review, Report of the Working Group on the Universal Periodic Review: Ireland (A/HRC/19/9, 21 December 2011) page 21 .

57 Marc Bossuyt, supra n 28.

58 Handyside v. The United Kingdom App no 5493/72 (ECHR 7 December 1976).

59 Egbert Myjer, supra n 33, p. 40. 
key players to effectively reform the Convention system. ${ }^{60}$ The Court's positive engagement with national courts, authorities and their representatives on the Committee of Ministers is vital to addressing these chronic issues. Such engagement will help national authorities to resolve violations, prevent further violations and, as a result, reduce the ECtHR's backlog and help to tame the backlash.

\section{Enhanced Role for the Committee of Ministers}

Under Article 46 ECHR the Committee of Ministers is responsible for ensuring that violations are resolved on the national level as part of the effective execution of the Court's judgments. Many of the authors in this volume, as well as the representatives of the member States in Brighton, have suggested that the Committee of Ministers should play a greater role in resolving human rights violations. The Brighton Declaration encouraged dialogue between the Court and the Committee of Ministers on topics including the subsidiarity principle and the clarity and consistency of the Court's case law. ${ }^{61}$ The Declaration also invited the Committee to consider whether more effective measures are needed in respect of States that fail to implement the Court's judgments in a timely manner - with particular attention paid to violations disclosing a systemic issue. ${ }^{62}$

Repetitive applications - currently around 34,000 pending before the Court - mostly arise from systemic or structural problems on the national level (such as excessive length of proceedings or dysfunction in the prison system). ${ }^{63}$ In order to address these cases in a meaningful and timely manner, Mahoney and Wildhaber recommended referring repetitive cases linked to a pilot judgment finding a violation to the Committee of Ministers rather than submitting them for adjudication by the Court.

\footnotetext{
60 Luzius Wildhaber, supra n 4, p. 12.

61 Brighton Declaration (20 April 2012) supra n 1, para 12(c)(ii).

62 Ibid, paras 27 and 29(d).

63 For example, in 2011 Turkey was found to have violated Article 6 ECHR length of proceedings 53 times and Greece 50 times; and Russia was found to have violated Article 5 ECHR right to liberty and security 68 times. European Court of Human Rights, Violations by Article and by State 2011 <www.echr.coe.int/NR/rdonlyres/596C7B5C-3FFB-4874-85D8-F12E8F67C136/ 0/TABLEAU_VIOLATIONS_EN_2011.pdf> accessed on 27 October 2012. See also Erik Fribergh, Registrar of the European Court of Human Rights, 'Bringing Rights Home: How to deal with repetitive applications in the future', Round table speech on ways of protecting the right to a trial within a reasonable timecountries' experiences - and short-term reform of the European Court of Human Rights (21-22 September 2009 Slovenia).
} 
This possibility was also raised earlier at the 2010 Interlaken High Level Conference. ${ }^{64}$ Mahoney compared the process of referring pending repetitive cases to the Committee of Ministers as similar to the concept of 'default judgment' in national courts. ${ }^{65} \mathrm{He}$ cautioned that procedural safeguards would be required to ensure that the Court retained control over the outcome. For example, if difficulties arose, the Committee could refer a matter back to the Court for an interpretive ruling on the pilot or lead judgment. ${ }^{66}$

Sajó, Gerards and Terlouw made similar suggestions, including a 'bounce back' procedure whereby applications that are well-founded according to settled case law are not dealt with by the ECtHR but remitted to the national authorities. ${ }^{67}$ Member States endorsed a comparable proposal in the Brighton Declaration by inviting the Committee of Ministers to consider the advisability and modalities of a procedure whereby the Court could determine claims in a collective process, not dissimilar to that adopted by mass claims bodies. It was proposed that the Court determine a small number of representative applications from a group that allege the same violation against the same respondent State, with the ultimate finding being applicable to the whole group. ${ }^{68}$ The study by Gerards and Terlouw suggested introducing 'smart' procedures to cluster such repetitive applications. ${ }^{69}$

As President of the Court, Wildhaber created a liaison position between the Court and the Committee of Ministers to facilitate communication. Myjer noted that the Court often refers to documents by the Committee on topics such as determining a European consensus. However, Zwart proposed a further role for the Committee in assisting the Court to be more strategic when dealing with sensitive moral cases. Zwart argued that the Court could increase its legitimacy by leaving such 'hot potato' cases to the Committee of Ministers to determine. ${ }^{70}$ Some scholars have noted that it may not be appropriate for judges, who lack a

64 European Court of Human Rights, Memorandum of the President of the European Court of Human Rights to the States with a View to Preparing the Interlaken Conference (3 July 2009) page 7.

65 Paul Mahoney, supra n 6, p. 23; and Luzius Wildhaber, supra n 4, p. 14.

66 Paul Mahoney, ibid, p. 24.

67 Janneke Gerards and Ashley Terlouw, supra n 17, p. 173; and András Sajó, supra n 3, p. 190.

68 Brighton Declaration (20 April 2012) supra n 1, para 20(d).

69 Janneke Gerards and Ashley Terlouw, supra n 17, p. 173.

70 Tom Zwart, in ibid. at 178. 
democratic mandate, to decide certain politically sensitive issues..$^{71}$ In this view, the Committee of Ministers would be a preferable decisionmaker for politically charged cases. However, it is also possible that such an approach may undermine the Court's legitimacy.

It is arguable that it is precisely the Court's responsibility to determine sensitive issues in the absence of a political bias. Deferring such cases to the Committee of Ministers would render decision-making less transparent and potentially less consistent and less fair. Thomassen noted little merit in the proposal to give the Committee an advisory role in the interpretation of Convention rights in sensitive cases. From a practical point of view, she stated that it is difficult to imagine an effective meeting of 47 ministers discussing abortion and euthanasia, precisely because they are politicians with potentially opposing political agendas..$^{72}$ Lacking consensus, the Netherlands Parliament was unable to rule on exactly these kinds of sensitive issues, which obliged the courts to deal with them. And that was within just one country and not between 47.73

\section{ECtHR's Relationship with National Courts and Authorities}

A strong theme across all of the chapters in this volume is that the relationship between the Court and national judicial institutions needs to be strengthened. The criticism coming from the national courts demonstrates that they are disengaged from the ECtHR's processes but are keen to be involved. A strong relationship between the ECtHR and national courts could facilitate enhanced application of the ECHR in member States, reinforce the subsidiarity principle and better protect human rights without recourse to Strasbourg. The Brighton Declaration affirmed the strong commitment of member States to fulfil their primary responsibility to implement the Convention on the national level. ${ }^{74}$ Embedding the ECHR in national legal systems and ensuring that member States more effectively resolve violations would reduce the workload of the Court and allow it to focus on the most serious cases and important questions of interpretation and application of the Convention. ${ }^{75}$

71 Jeremy Waldron, 'The Core of the Case Against Judicial Review' (2006) 115 Yale LJ 1346.

72 Wilhelmina Thomassen, supra n 32, p. 103.

73 Ibid.

74 Brighton Declaration (20 April 2012) supra n 1, para 9(a).

75 Ibid, paras 3 and 33. 


\section{Dialogue and interaction between the ECtHR and national courts}

Sajó has called for an all-European conversation on the meaning and value of European human rights. ${ }^{76}$ Such a conversation would entail information flowing from the ECtHR to national courts and vice versa. As one can glean from the chapters of this volume it is essential for the viability and credibility of the Convention system that information flows in both directions. Kerr recommended greater exchanges between Strasbourg and national courts stating that the best way to diffuse ill-informed criticism is by allowing such a free flow of information. ${ }^{77}$ It is submitted that this method will not only diffuse ill-informed criticism, but also assist the Court to take on and remedy relevant and pointed criticism.

While some amount of tension is to be expected between the supervisor and the supervised, there are some positive examples of interaction between the ECtHR and national courts. Thomassen stressed that the ECtHR's case law provides national judges with a source of legal reasoning and interpretation that can be compared to the reasoning of national governments, judges and individuals on specific issues. ${ }^{78}$ Equally, Kerr noted that national courts must explain in sufficient detail why a particular stance was taken in a case, as this enables Strasbourg to understand the local circumstances that led to the decision and why an alternative outcome may create difficulties for the administration of justice in that setting. ${ }^{79}$ Citing the Grand Chamber's revision of the Chamber decision in Al-Khawaja and Tahery, both Kerr and Thomassen highlighted Strasbourg's ability to amend its view when a national court convincingly explains that the ECtHR's judgment was based on a misunderstanding of national law. ${ }^{80}$ Sajó has lamented that the ECtHR does not receive the required level of input from a number of countries in a number of cases.

In order to increase interaction, as noted by Sajó, some States have expressed interest in a procedure that would allow the highest national courts to request advisory opinions from Strasbourg concerning the

\footnotetext{
76 András Sajó, supra n 3, p. 190.

77 Lord Kerr of Tonaghmore, 'The need for dialogue between national courts and the European Court of Human Rights', chapter 10, p. 105.

78 Wilhelmina Thomassen, supra n 32, p. 97.

79 Lord Kerr, supra n 77, p. 105.

80 Al-Khawaja and Tahery v. The United Kingdom, App nos 26766/05 and 22228/06 (ECHR 20 January 2009); and Al-Khawaja and Tahery v. The United Kingdom App nos 26766/05 and 22228/06 (ECHR Grand Chamber 15 December 2011). See Wilhelmina Thomassen, supra n 32, pp. 97; and Lord Kerr, supra n 77, pp. 107-109.
} 
interpretation and application of the Convention. ${ }^{81}$ This was reflected in the Brighton Declaration, which invited the Committee of Ministers to prepare an optional protocol that would allow the Court, upon the request of a State, to deliver advisory opinions on the interpretation of the Convention in a specific case at the domestic level, without the opinion binding other member States. ${ }^{82}$ While potentially to be welcomed as a tool to increase dialogue, Dzehtsiarou submitted that such a reform could potentially add to the Court's enormous backlog of work and, due to the non-binding nature on other States, also lead to anomalous results. ${ }^{83} \mathrm{He}$ urges the Committee of Ministers to carefully consider all the legal and practical implications of so extending the Court's advisory jurisdiction. ${ }^{84}$

\section{Promotion of the ECHR and the Court's case law}

The Brighton Declaration encouraged all national courts and tribunals to consider the Convention and the ECtHR's case law in order to reduce both the number of human rights violations as well as the workload of the Court. ${ }^{85}$ A number of authors in this volume stressed the huge scope for improving national implementation of the Convention by increasing judges' and lawyers' knowledge of the ECHR and the Court's case law. Bradley noted that such knowledge may be limited even in countries where the national constitution or other legislation claims to give effect to international law and/or the rights guaranteed by the Convention. ${ }^{86}$ Moreover, he suggested that all systems of legal education in Europe should include subjects on the areas of law relating to the Convention as well as the Court's principal decisions. ${ }^{87}$

Reiterating this need, Burkov noted that graduates of Russian law schools do not have any obligatory coursework relating to the Convention and that, in general, education on the Convention is lacking. ${ }^{88}$ Equally, Gerards and Terlouw commented that the level of knowledge of human

\footnotetext{
81 András Sajó, supra n 3, p. 190.

82 Brighton Declaration (20 April 2012) supra n 1, para 12(d).

83 Dzehtsiarou, supra n 44, pp. 131-133.

84 Ibid, p. 133.

85 Brighton Declaration (20 April 2012) supra n 1, paras 7 and 9(c)(iv).

86 Anthony Bradley, 'The need for both international and national protection of human rights: the European challenge', chapter 1, p. 7.

87 Ibid.

88 Anton Burkov, 'How to improve the results of a reluctant player: the case of Russia and the European Court of Human Rights', chapter 13, p. 153.
} 
rights in the Netherlands is 'shockingly low' ${ }^{89}$ Cognisant of this problem, the Brighton Declaration encouraged States to provide training on the Convention in the professional development of national judges, lawyers and prosecutors, as well as providing public officials - including those in the justice system, law enforcement and detention - with relevant information about how to fulfil their obligations under the Convention. ${ }^{90}$

Information and education alone is, however, not enough. Burkov asks whether national legal systems are both familiar with the Convention and the Court's case law and interested in applying it? He notes that it is not enough to just persuade lawyers to make Convention based arguments as often the Russian courts simply ignore such arguments - despite a 2003 Regulation instructing national courts to consider the practice of the ECtHR. ${ }^{91}$ Burkov claims that the most important barrier to national implementation of the Convention and ECtHR case law is the attitude of national litigators and judges who often lack awareness of the Convention as well as the motivation for learning about it and applying it. ${ }^{92}$

This view has been supported using the example of Serbia, which also has a lacklustre record of implementing the ECHR and the Court's jurisprudence. ${ }^{93}$ This is despite the fact that according to the Serbian Constitution, all constitutional provisions on human rights are to be interpreted as in accordance with international human rights bodies and courts - including the ECtHR. ${ }^{94}$ In contrast, Bradley recalled that the UK Human Rights Act 1998 imposes a duty on every court or tribunal to take

89 Janneke Gerards and Ashley Terlouw, supra n 17, p. 177.

90 Brighton Declaration (20 April 2012) supra n 1, para 9(c)(v) and (vi).

91 And also despite the fact that under Article 15(4) of the Russian Constitution the ECHR is part of the Russian legal system and has priority status in application as compared with national legislation. See Anton Burkov, supra n 88 , pp. 150 and 155 .

92 Ibid, p. 154.

936.7 per cent of applications pending before the Court as of 30 September 2012 were from Serbia, making it the sixth greatest source of applications to the Court. European Court of Human Rights, Pending Applications Allocated to a Judicial Formation (30 September 2012) <http://www.echr.coe.int/ECHR/EN/ Header/Reports+and+Statistics/Statistics/Statistical+data/>, accessed on 13 October 2012.

94 Article 194 of the Constitution of the Republic of Serbia provides that 'Ratified international treaties and generally accepted rules of the international law shall be part of the legal system of the Republic of Serbia.' <http:// www.srbija.gov.rs/cinjenice_o_srbiji/ustav_odredbe.php?id=226> accessed on 13 October 2012. 
into account the ECHR and that training was provided for judges. He notes that one can now find discussion of the ECHR even in lower level UK courts. ${ }^{95}$ Increased education efforts coupled with national incentives or instructions can deliver the desired results of better ECHR implementation nationally. The ECtHR should engage with national courts and authorities to facilitate this, providing the requisite knowledge on the Convention and case law as well as motivation. ${ }^{96}$ As Kerr noted, national courts and the ECtHR will not only have much to say, but also much to learn from one another. ${ }^{97}$

Of formidable importance according to Gerards and Terlouw's study, is that national judges, civil servants and scholars are engaged in the process of safeguarding the future of the Strasbourg Court. ${ }^{98}$ The Brighton Declaration reminds us that the Convention system must support States in fulfilling their primary responsibility to implement the Convention at the national level and that together, the Court and member States share responsibility for ensuring the viability of the Convention system. ${ }^{99}$ What is indispensable according to Myjer is that the Court remains strong and able to fulfil the supervisory role for which it was designed - and that this can only be done with the cooperation of member States. ${ }^{100}$

\section{CONCLUSION: THE ROAD AHEAD FOR THE EUROPEAN COURT OF HUMAN RIGHTS}

As is apparent from the chapters in this volume, the interrelated issues of the Court's 'backlog and backlash' have no easy solution, nor are they going away. As Bojin aptly stated, it is clear that the 'Strasbourg Court is currently facing, besides mere criticism, real challenges'. ${ }^{101}$ Reform must be made to the Court's application and admissibility process and potentially to the individual petition system, to reduce the number of applications before the Court. The Committee of Ministers could play a greater role, both in dealing with applications and ensuring compliance

95 Anthony Bradley, Conference entitled 'How to deal with the criticism of the European Court of Human Rights (12-13 April 2012), The Hague.

96 Janneke Gerards and Ashley Terlouw, supra n 17, pp. 166-167.

97 Lord Kerr, supra n 77, p. 114.

98 Janneke Gerards and Ashley Terlouw, supra n 17, p. 167.

99 Brighton Declaration (20 April 2012) supra n 1, paras 4 and 32.

100 Egbert Myjer, supra n 33, pp. 51; and András Sajó, supra n 3, pp. 189-191.

101 Lucian Bojin, supra n 18, pp. 54 and 63. 
with judgments on the national level. National courts and authorities must better protect human rights at home, particularly regarding systemic issues, by implementing the Court's case law. This could be assisted by enhanced cooperation and interaction between the ECtHR and national courts, as well as by increased education and awareness of the Convention system nationally. Enhanced dialogue could also help to address the backlash, by improving the relationship and understanding between the ECtHR and national court and authorities.

The Brighton Declaration noted that a process is needed to develop a 'vision for the future of the Convention' and that as part of this process it may be necessary to evaluate the fundamental role and nature of the Court. ${ }^{102}$ The longer-term vision for the Convention system must secure the viability of the Court's role in protecting and promoting human rights in Europe. ${ }^{103}$ Reform must ensure the Court's vitality, effectiveness and authority for the benefit of Europe and everyone within the ECHR's jurisdiction. The sustainability of the Court's processes should ensure that it remains the central part of the most advanced human rights regime in the world.

Ultimately, as posed by the Court in its preparation for the High Level Interlaken Conference, States should ask themselves the following questions: what sort of Court of Human Rights do they want for the future? What sort of machinery are they prepared to finance? What should it deal with? ${ }^{104}$ The authors in this volume would agree that such an evaluation is essential. All actors within the Convention system (national authorities, individuals, scholars, NGOs, practitioners, judges and politicians) should contribute to forming this vision of the Court - in effect, an all-European conversation on the future of human rights protection.

\footnotetext{
102 Brighton Declaration (20 April 2012) supra n 1, paras 30 and 31.

103 Ibid, para 31.

104 European Court of Human Rights, Memorandum of the President of the European Court of Human Rights to the States with a View to Preparing the Interlaken Conference (3 July 2009) page 3.
} 